\author{
Unter Berücksichtigung des \\ Gegenstandskataloges für die Ärztliche Prüfung
}

Mit ICD 10-Schlüssel im Text und Stichwortverzeichnis

\title{
INNERE MEDIZIN
}

Eine vorlesungsorientierte Darstellung

\section{9}

\section{GERD HEROLD}

\author{
und Mitarbeiter
}

